\title{
RE-CONCEPTUALIZING JOINT CONSULTATIVE COMMITTEES IN PUBLIC HIGHER EDUCATION SECTORS IN MALAYSIA
}

\author{
Badariah Ab Rahman', Dzurizah Ibrahim² and Rosazman Hussin ${ }^{3}$ \\ ${ }^{1}$ Candidate Doctor of Philosophy, University Malaysia Sabah, Malaysia, \\ badariah_abrahman@ums.edu.my; badariah_abrahman@yahoo.co.uk \\ 2 Dr. University Malaysia Sabah, Malaysia, idzuri@ums.edu.my \\ ${ }^{3}$ Assoc. Prof. Dr., University Malaysia Sabah, Malaysia, azzs@ums.edu.my
}

\begin{abstract}
Employee Participation (EP) enhances the quality of decision-making by broadening inputs, promotes commitment to the outcomes, improved motivation, co-operation and communication in the workplace. EP also may reduce workloads of supervisors, encourage skill development in the workforce and can contribute to improved employee relations. There are two forms of EP; direct and indirect. Joint Consultative Committee (JCC) is the most preferred indirect mechanism of workers representation in the UK and other English spoken country such as Australia, New Zealand and the US (Heller, et al. 1998; Parasuraman and Jones, 2006). In the developed countries, the Work Council, a similar structure as JCC can be found in Western Europe (the Netherlands) is the most effective workers representation in EU following the EU Directive 2002 for Information and Consultation (ICE) (Markey, 2010; Goodijk, 2010; Arrigo and Casale, 2010). The ICE has been extended to the UK which has boosted the interest on JCC (Kougiannou, 2013). However, the JCC system and practices in public higher education sector in Malaysia remained to be unknown. This paper discusses on the system and practices of JCC in a public higher education sector in Malaysia. The authors focused on three aspects: what, why and how JCC formation in the public higher education sector, their limitation, evaluation and improvement. The research findings indicate that JCC in public higher education sector was ineffective and re-conceptualizing of the JCC Model is required urgently in order for JCC to be relevant and effective. Therefore, certain modification to the JCC Model is essential to suit the public higher education sector environment in Malaysia.
\end{abstract}

Keywords: Employee Participation, Joint Consultative Committee, Indirect Mechanism, Public Higher Education.

\section{INTRODUCTION}

The aim of this paper is to highlights on the emerging issues with regards to the extensiveness of JCC in a public higher education sector in Malaysia, particularly the public universities. The objectives of the research are to (i) explain the proses of the Academic JCC formation and implementation in the public higher education; (ii) explore the role and function of the Academic JCC in public universities, to address their limitation and subsequently to evaluate for improvement. 


\section{THE NEED TO RE-CONCEPTUALIZING THE ACADEMIC JCC IN PUBLIC UNIVERSITIES}

It is very important to note that, the need to re-conceptualizing the Academic JCC is based on the following reasons.

The establishment of the Academic Joint Consultative Committee (JCC) is not new because it has been placed in the public higher education, particularly the public universities in Malaysia. However, the Academic JCC was still being managed in the traditional way (Gollan and Lewin, (2013). In the current business environment exposure, there is an urgent need to do some review on how to turn the Academic JCC into a valuable mechanism for public universities and at the same time functions as an effective employee representation to achieve positive outcomes. The idea to undertake the research is based on, these considerations. Firstly, the Academic JCC in public universities is already a reality (MTUC 2010; Che Rose 2010; CUEPACS, 2010; 2015). Secondly, the research on effectiveness of the Academic JCC is still falling short in public sectors, particularly the public universities (Ab Rahman, 2012). Thirdly, need to benchmark the Academic JCC with the developed countries, such as in the Western Europe (Idrus, 2010; Che Rose, 2010; MTUC, 2010; CUEPACS 2010; 2015). Lastly, it is very critical to examine factors that hinder the Academic JCC effectiveness in public university environment in Malaysia (Ab Rahman, 2012) in order to maintain its relevancy and to position the Academic JCC at its primary place.

Academics being group of intellectual people in a university environment should not be treated traditionally as normal JCCs. The academics are scholars, who profess in their related field of expertise and naturally be given some freedom to voice their views to the universities management so as to enhance the academic matters. It is therefore, giving opportunity for the academics demands a great understanding on the concept of employee voice. It requires the management and the Academic JCC participation to mutually respect on each other existence in organization. The desire to make JCCs a meaningful platform to others, giving voice to employees would require readiness from the part of management-Academic JCC-Academicians.

\subsection{Public Universities in Malaysia}

Malaysia has twenty (20) full-fledged public universities under the control of Ministry of Education. The public university can be categorized into APEX University (1), Research University (4), Comprehensive University (4) and Focused University (11). Being owned and funded by the government, the public universities must ensure their strategic directions are in line with the Ministry of Education. The Ministry has drawn up a Blueprint on The National Higher Education Strategic Plan 2007-2010: Laying the Foundation Beyond 2020 aimed to drive all public universities to work at their level best to assist the government to achieve its aspiration. This requires every department, every sections and units to unite in order to stimulate activities that focused to direction of the Ministry. At this point of view, it is very essential for the public universities to recognize the potential of the Academic JCC, which were normally left unattended in every endeavour of the university (Ab Rahman, 2012). However, as a statutory bodies of the government the public universities, there is no presence of union (CUEPACS, 2010; MTUC, 2010; Idrus, 2010; Che Rose, 2010). Alternatively, employee representations were established to represent three categories of employees in the organization namely the Admin and Professional JCC, the Academic JCC and the support Staff JCC (CUEPACS, 2010; Ab Rahman, 2012) in line with the Service Circular No. 7, 1979 and No. 2, 1989 respectively.

\subsection{The Aspiration of Vision 2020}

Under the national aspiration of Vision 2020, the Government expects the public universities to produce highly skilled, talented, motivated workforce in preparation to move to a developed and high income nations by year 2020. The challenge is in the hand of public university to draw an effective execution strategy to achieve the national aspirations. The nation call reflects the Academic JCC can no longer be managed in a traditional manner. Therefore, the Academic JCC is seen to be the most appropriate indirect participation that can be used to enhance employee engagement in organization. In this context, the Academic JCC have been in existence for the past five years and it is therefore, the need to re-conceptualizing the Academic JCC should be the top priority. The Academic JCC must be given better task in order to help the university to grow. A senior academician commented, "management should not regard the Academic JCC as a threat, instead take them as partners in the organization with due respect we are lecturers". It is very timely for the role and function of the Academic JCC need to be redefined, relook and be given a new dimension and direction, to work hand in hand with the management to drive the university into greater heights. It is up most important to position the Academic JCC as important stakeholders in a public university environment. 


\subsection{Contemporary trends on employee involvement and participation}

Across the diverse context of Europe, the contemporary trend of employee relations environment is in the period of significant change, where the traditional practice of JCCs has lost some of its significance (Gollan and Lewin, 2013). In addition Strauss, (1998) exerted that, the effectiveness of direct participation will be restricted if it is not combined with indirect participation, thus EP will not take place effectively. Strauss arguments supporting indirect participation have strong significance because many high level decisions affect the mass of employees who work within the organization. Cox, Marchington and Suter. (2009, p. 16) introduces a new innovation work, that is employee involvement and employee participation combined (EIP). Markey and Townsend, (2013) argued that, there should be an integrated approach on the way EP supposed to be treated. The traditional way of viewing EP where indirect participation is seen to be separated from direct participation is no longer significant because in most cases many strategic direction of organization is usually a determinant of the employee's actions and beliefs. This argument suggests that high level company decision should be made in consultation with employees' representatives.

\subsection{Research on JCC}

Most of the studies are based on Western culture (Parasurman and Jones, 2006; Heller, et al. 1998; Goodijk, 2010; Kougiannou, 2013). Research on JCC abroad has indicated that JCC are the most preferred indirect participation mechanism of workers representation in the UK and other English spoken countries such as Australia, New Zealand and the US (Heller et al. (1998). The Work Council, a similar structure as the JCC can be found in Western Europe countries such as the Netherlands is the most effective form of workers representation in European Union (EU) following the EU Directive 2002 for Information and Consultation (Markey, 2001; Goodijk, 2010). In addition interest on JCC in UK has recently boosted by the introduction for further legal regulation via Information and Consultation of Employees (ICE) (Kougiannou, 2013). According to Kougiannou, (2013), the early research on the impact of ICE Regulation suggest that consultation practice is still "evolving" and this has attracted scholars, researchers, practitioners and management writers on a number of issues ranging from their impact on organization to debates about the usefulness as an employee voice mechanism (Heller, et al. (1998); Gollan, et al. (2001); Kougiannou. (2013).

The empirical study on the extensiveness of JCC in the Malaysian context has been focusing for the private sector (Parasuraman and Jones, 2006; Parasuraman, 2007; Koiker, 2010). It is an evident JCC in the public university were less emphasized; thus the knowledge on the extensiveness of JCC remained to be unknown and the gap is widening. There is a dearth of literature on the extensiveness of the JCC in the public universities. JCC is an important research and there is a need for the public universities to understand the importance of giving voice to the employees through the use of the Academic JCC. The importance of JCC has been highlighted by Marchington, (1992), he reiterated that JCC helps to reduce industrial action and provides an avenue for employee to express their view (Okpu and Jaja, 2014). This research work is therefore carried out to fill the gap in the literature by examining the extensiveness of the Academic JCC in a public university in Malaysia.

\section{JCC: AN OVERVIEW OF THE LITERATURE}

JCC is a form of indirect participation that provides platform for information and communication at the enterprise level. It is a formal system of communication between management and employee representatives mainly to discuss the operational and strategic issue on work and work method (Marchington, 1992; Hyman and Mason, 1995; Okpu and Jaja, 2014). The formal system enables managers and management to meet on a regular basis in order to exchange views and utilize members knowledge and expertise in dealing with common interest that are not the subject of CB (Marchington, 1992). According to Marchington, (1992) and Parasuraman and Jones, (2006), employers introduced JCC for several reasons. Firstly, JCC can enhance efficiency by increasing stock of ideas which are available in the organization. Secondly, JCC is able to reduce industrial action (Hyman and Mason, 1995:125) as JCC is able to provide platform for communication channels. Thirdly, the JCC may lead to increased employee satisfaction (Rose, 2002). While Markey (2007, p. 138) exerted that the attention given to JCC because of the declining trade unions membership in most countries. Hyman and Mason, (1995), claimed that JCC is formed to undermine the power of union.

JCC have been variously viewed as both positive and negative instruments for organizations (Marchington, 1992; Ramsay, 1983; Hyman and Mason, 1995; Beardwell and Holden, 2001). Among others, Marchington, (1992) exerts that "both managers and employees values JCCs as a meaningful form of involvement and participation". Ramsay, (1983) under his famous "Cycle of Control Theory" argues that "JCCs can be used to undermine the power of unions at workplaces". Hyman and Mason, (1995) pointed that JCCs can either be a management dominated forums or act as mechanism for enabling employee representatives to influence the aspect of organizational decision making. In contrast, Beardwell and Holden, (2001) sees JCCs merely as "a 
rubber stamping bodies" for management initiatives which focus on issues like "tea, toilets and trivia". Therefore, it can be concluded that JCCs can play different roles in organization effecting different outcomes depending on the selected mix of the primary components as defined by Marchington, (1992).

Based on the arguments above, Marchington, (1992) explained that there are at least five primary components and models in relations to JCCs effectiveness in organizations. However, these models have not been theoretically tested in Asia.

\subsection{The Five Primary Components of JCC in Organization}

First, the objective of JCC should be explicitly written in the constitution so as to improve productivity and efficiency, and to enhance employee commitment to organizational decision-making. However, there is another argument from radical perspectives, for example in order to improve organizational performance through JCC; management must introduce tight work councils, which disadvantage employees. Therefore employers can use JCCs to hide an agenda which may undermine union influence in the workplace decision making process (Ramsay, 1983; Parasuraman and Jones 2006; Ab Rahman, 2012).

Second, is subject matter refers to the focus of JCC meeting. The range of subject JCCs may be charged to discuss can vary from minor issues such as social and welfare activities, the quality of canteen food, toilets, and parking, through matters of strategic importance such as company investment plans and business projections (Markey and Monat, 1997; Parasuraman and Jones, 2007; Ab Rahman, 2012).

Third, the process of consultation can also vary considerably and the flow of information can be either upward or downwards or both. An upward flow is usually intended to capture suggestions or recommendations from the shop floor, and is geared to benefit the company through the combined experience and knowledge of the employees (Marchington, 1992). Downward information flow in the other hand intended to persuade employees to accept management proposals (Marchington, 1992:135).

Fourth, is the issue of power. It is inevitable that power differential will exist in an organization; these struggles may not be dissipated through the process of JCC. Marchington, (1992) argues that in firms with a strong union membership the inequality of power may be focused towards the benefit of employees.

Fifth, is the membership of the JCC. Consultative committees normally comprise a member of senior management (personnel or HR department), a line manager, and employee and union representatives.

\subsection{The Critiques on JCC Model in the Public Universities Context}

The emergence of JCC as an indirect participation mechanism in the public sector can be traced back through the historical underpinnings. The hierarchical structure in public sectors in Malaysia was inherited from the British administration system (Zin, 1998; Idrus, 2001; Aminuddin, 2002; Parasuraman, 2007). The hierarchical structure are known as the "Whiltley Committee" and can be found in all government departments and is still apparent in the public sector until today that practices the highest degree of hierarchical system and have the power to rule, instruct and to divide on how work should be done. A Senior Officer of CUEPACS explained, "The joint consultative committee in the public sector was originated from Whitley Committee. We have changed it to Majlis Bersama Jabatan according to our needs". Therefore all public sectors in the country have established their JCC in accordance to the requirements.

The critiques on the JCC Model in public universities can be determine as the emerging issues that need to be further refined and relook. Firstly, the JCC Model was not sufficient in the public university environment simply because the model was introduced for the Western setting (Parasuraman, 2007; Markey, 2009). Further to that, the highly bureaucratic administration system in public sectors in Malaysia was a direct influence from the British administration (Idrus, 2010; CUEPACS, 2010; MTUC, 2010) known as the Whitley Committee; the origin of JCC. Secondly, the JCC is more apparent in the public sector, particularly in the public universities. Thirdly, the JCC is a universally accepted model; it is a global knowledge against the local culture of Malaysia, taking into consideration of the composition of multi-ethnicity of the people in Malaysia. Lastly, the culture aspect of JCC was not thoroughly discussed in the context of public universities in Malaysia; thus the extensiveness remained to be unknown until today. The said JCC Model is as per in Figure 1. 


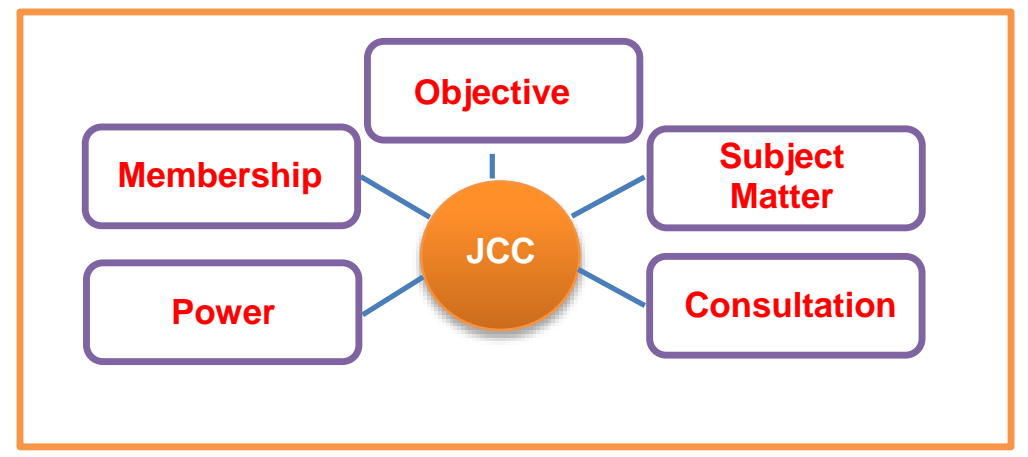

Figure 1 JCC Model (Marchington 1992)

\section{THE RESEARCH METHOD}

The research was undertaken in a public university in Malaysia. The methodology used was based on a qualitative case study approach using the multi-method techniques (Kelly, 1999; Yin, 2003). Over a period of ten weeks, senior officers at the university level and a cross sectional of JCC participants were interviewed and observed; interviews were transcript and compiled. In addition various documents were obtained from the unions and management, the analysis of which was added to the overall empirical report. However, this case study cannot be generalized to represent the extent and the process of JCC in other public universities in general (Parasuraman, 2009). Even though the methodology used mix-method techniques, this paper presents the analytical views from respondents' perspective and not statistical generalization (Mitchell 1983). In addition, generalization also seen on present understanding on the existing literature, or on the decision of experimental specialist based on the argumentative dialogues on JCC (Parasuraman, 2009). For ethical and confidential issues, the location understudy remained to be anonymous.

\section{THE ROLE AND FUNCTION OF THE ACADEMIC JCC}

This section presents the result on the role and function of the Academic JCC from (i) management and Academic JCC participation perspectives, and (ii) Academic JCC members' perspectives.

The Academic JCC has been viewed as positive and negative mechanism in the university.

\subsection{The Role and Function of the Academic JCC from Management and Academic JCC Participant}

A total of five (5) university officials were interviewed on the concept of EP. Generally, the management views were very positive. Senior Officer 1 said, "The Academic JCC is a vehicle for academician to voice their concern to the management". The Academic JCC participants 2 are of the opinion that "it is a platform for information and communication and established to look into the welfares of the academician". However the management views the Academic JCC negatively, "the Academic JCC often brought up issues that relates to money, money, money. They are not helping the university to grow". While the Academic JCC participant commented, "JCC works very well in the private sector, not in the public sector because we cannot touch matters related to policies, regulations and management prerogatives".

\subsection{The Role and Functions of the Academic JCC from Members Perspectives Based On JCC Model}

Objective: The objectives of the Academic JCC has been published and made available online. However, the objectives were not clearly defined. Respondent 1 commented, "We are not given a copy of the constitution, and there is no information delivered to us on the objectives of the Academic JCC". Respondent 2, "the Academic JCC is lacking of publicity, I don't really know what the Academic JCC can do for me" while Respondent 3 commented, "we don't know the website exist". It is very clear from the evident, that the objectives of the Academic JCC were not fully understood by the members. It is therefore, the objectives must be clearly defined because ill-defined objectives lure too many misunderstanding and misconception on the noble cause of the Academic JCC.

Subject Matter: Through documented data, it is an evident that the academic JCC concentrates more on nonacademic issues such as recreational activities that is scuba diving, football matches and so on. Respondent 
4 views, "we don't need another recreational club, what we need is a body which is powerful and strong to represent us to the management. At the moment the Academic JCC makes themselves busy with nonacademic matters and portrays like they are fighting for the academics". Subject matter is the most important key for decision making process that should be optimized by the Academic JCC. In this respect, the member has perceived that the Academic JCC was not effective in representing members' issues to the management.

Consultation: The academics felt that the Academic JCC does not interact effectively with the members. Respondent 5 claimed that, "we don't know what transpired in the meeting with management and no news whether they voice out our problems and welfares. They only voice their personal agenda to the management". The members also said that very seldom the Academic JCC talked or listened to them, Respondent 6, "no one from the committee members of the Academic JCC come and talk to us on our needs, to understand us". In terms of conducting meetings with the management, the Vice Chancellor and the President of the Academic JCC is the co-chairman of the meeting. In this situation, it is always the Vice-Chancellor chaired the meetings. Respondent 7 commented, "The VC chaired all the meetings; any matters which required urgent action, VC will decide as long as it is not on policy matters". In this regard, the members has perceived that the consultation process were practically absent between the Academic JCC and the members before meeting the management; thus not effective.

Power: In this case, the academician views the Academic JCC as powerless. Respondent 8 said, "the real power is in the hand of the higher administration, we do nothing for sure!". On the other hand, there are some claims that the academic JCC is just a management machinery to get things done in accordance with the management desires. Respondent 9 said, "The Academic JCC is a toothless tiger, in fact they are the allies to the management". It is therefore, the members perceived that the Academic JCC has no capacity to influence the management decision making process; therefore not powerful.

Membership: In this aspect, the academician felt that the membership is in the situation of conflict of interest because, the Academic JCC committee members were also holding higher administration position in the university. Respondent 10 commented, "I don't believe that the Academic JCC can fight for my rights as academician because the top management are also the members of the Academic JCC; conflict of interest!!".

The above situation gives an impression that the Academic JCC is a weak representation to the academics. It is a fact that through the analysis, most academicians felt the Academic JCC has not been truthful in executing its role and function; therefore seen to be not the right body for them to seek for help. The other factors which is important to note that the reason for the academic feeling awkward is because of the Academic JCC participation apparently holds high administrative post and in the situation of conflict of interest. Therefore, the Academic JCC cannot execute their duties effectively.

\subsection{Ineffectiveness of the Academic JCC as the Preferred JCC Model}

Marchington, (1992) has expressed that, for a JCC to be effective, the five primary components must correspond and relate with one another. Based on the evaluation, the case study has shown that the Academic JCC has not been effective as the academic representatives. There are several reasons that contributed to the weak representation by the Academic JCC. Among the noticeable factors is this body was established upon the directive of the Government, therefore it is established in the system but it is not position anywhere in the hierarchical structure of the universities; nor being regarded as the university stakeholders. The public universities are now experiencing great transformation; however Academic JCC often left unattended unconsciously and in the situation of alienation (Ab Rahman, 2012). It is very critical to remedy this situation because the Academic JCC should be given the opportunity to transform itself into a respectful body as suggested by Hyman and Mason, (1995, p. 123) where employee representation must have legitimacy in the eyes of the work force, where the management must regard the Academic JCC as important stakeholders, not as same as other JCCs available in the universities.

Another important factor for consideration that both management and the Academic JCC must recognized the different techniques can be distinguished on the extent to which the Academic JCC influences the final decision. Marchington, (1992) exerts, JCCs can range from employee simply being informed by management through two-way communication, or discourse, consultation, co-determination, to some form of employee or joint control. In this aspect, the Academic JCC should ask for better function to transform as a meaningful platform that promotes professionalism of the academic. The Academic JCC as an indirect participation mechanism which already exists can be an effective platform for information, communication and consultation in a university environment serving both the management and members.

The research however confirms that the Academic JCC is facing problems related to (i) Lack of Information, Communication and Consultation; (ii) Lack of Confidence and Trust between Management-Academic JCCAcademician; (iii) Lack of Confidence to the Leadership of the Academic JCC; (iv) Lack of capacity to influence 
the final decision making; and (iv) Lack of support and commitment from the senior and experienced academicians.

\section{THE CHALLENGES AND CONSTRAINTS OF THE ACADEMIC JCC AS THE PREFERRED JCC MODEL}

The JCC model does not apply in the context of Malaysian public universities environment. This is in line with Parasuraman, (2009), indicated that the issue of multicultural ethnicity has some influence towards the management style in the Malaysian context. Zahari, (2013) analyzing the impact of cross-cultural on participative decision making in organization using the Hotsfede, (1991) cultural dimension on power distance. This dimension has strong impact on the level of EP in the workplace. Parasuraman, (2009) argument was high power distance cultures, responsible for the authority in decision making where the power to decide vested in the hand of a few at the top and delegation is avoided. He further exert that the belief that parties in organization are unequal implies that those higher in the position are more knowledgeable and experience and therefore should be respected and trusted to give the right decision. In the lower distance cultures, everyone is perceived to have the potential to contribute to the decision making process.

The study on the extensiveness of JCC apparently has some influence on the power distance culture (Parasuraman, 2009) and (Zahari, (2013). Higher power distance culture has direct impact on JCC based on the multicultural environment in Malaysia. This can be proven from the perceptions from the management and members of Academic JCC participant and the members in regards to its roles and functions. It is an evident that the management makes decision without consulting the Academic JCCs where the management is perceived as the authority to make decision without consulting their employees through the Academic JCC. Most of the developing countries including Malaysia, are still struggling to achieve a balance for effective participation (Parasuraman and Jones, 2006). EP has been widely accepted in organization in the developing countries such as South Korea, The Philippines and Indonesia to drive for success through numerous HR approaches programme such as TQM, ISO, QCC, KAIZEN and 5s (Cabrera, Ortega and Cabrera, 20002; Salamon, 1998; Idrus, 2001; Parasuraman, 2006). The indirect participation such as JCC, were left behind in many ways. Therefore the issues on power distance have to be rectified immediately to a more professional manner in executing their responsibilities to the management as well as to the members.

By looking at the development of EP from other countries, notably indirect participation has evolved into a remarkable progress where they are now moving towards professionalism in discharging their responsibilities (Goodijk, 2010; Markey, 2010). The Work Council in Western Europe has reached to co-determination stage respectively. The Work Councils has a legal standing and has the right for information, communication and consultation to co-determination with the management which reflects the power of Work Councils. In most cases, the management is not merely consults but also do joint decision together with the Work Councils (Marchington, 1992; Hyman and Mason, 1995; Markey, 2001). In this aspect, the Academic JCC in the public universities is left far behind in many ways compared to the development of JCC in developed countries (Ab Rahman, 2012). This factor is indeed the biggest challenge in the Malaysian context particularly in the public sector in Malaysia.

\section{CONCLUSION AND IMPLICATION}

Malaysia, a country aspired to be a developed and high income nation by year 2020 . The public universities have quite a handful responsibility to achieve the aspiration by producing highly skilled, talented and motivated workforce for the country. There are so many things to be done in order to prepare ourselves into that direction. The Academic JCC seems to be the most appropriate mechanism in creating balance between the direct and indirect participation in a university environment.

The literatures discussed earlier have mentioned some positive aspects of JCCs that can be used. Among the discussion are as suggested by Marchington, 1992; Hyman and Mason, 1995; Strauss, 1998; Markey, 2001; Goodijk, 2010). First, JCCs can give advisory role to the management; Second, JCCs can also play dual role that is as informant to the management and as an effective employee representation concurrently. Third, JCCs can have more power on strategic issues; Forth, JCCs can have additional jurisdiction on company investment activities, safety and health, ad-hoc and special tasks force, change agent on organizational restructuring, mergers and acquisitions. However, at present, the university management was not optimizing the Academic JCC to the fullest as suggested in the literatures.

Based on the previous empirical studies in the private sector, it was suggested by Parasuraman and Jones, (2006) that the possible element that makes the JCC not effective, got something to do with the Malaysian culture. Subsequently, a research was conducted by Koiker, (2010) who conducted research on JCC in Dutch firms in Malaysia also indicated that the Malaysian culture have direct influence on how JCC operates. Ab 
Rahman, (2012) conducted on the effectiveness of JCC in the public sector also suggested that the culture element should be added to the existing JCC Model to suit the public sector environment.

The proposed JCC Model Modification is as in Figure 2 and 3 below for comparison.

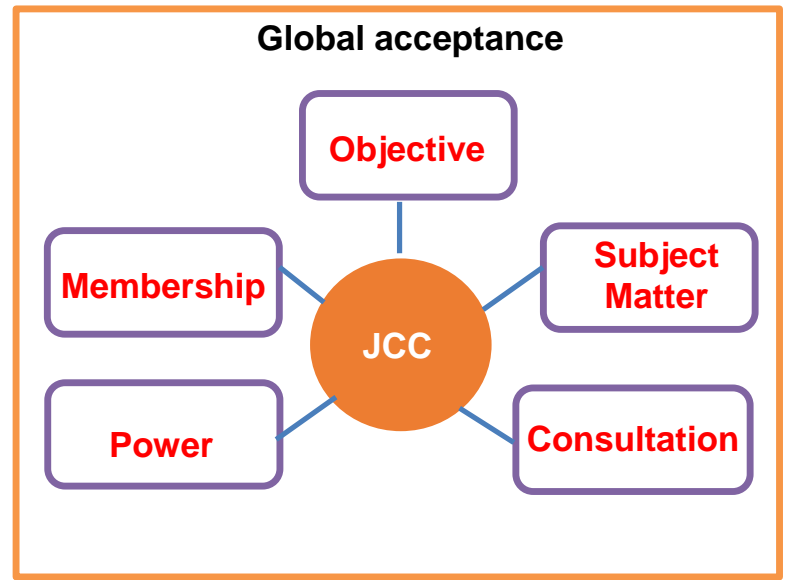

Figure 2 existing JCC Model in practice

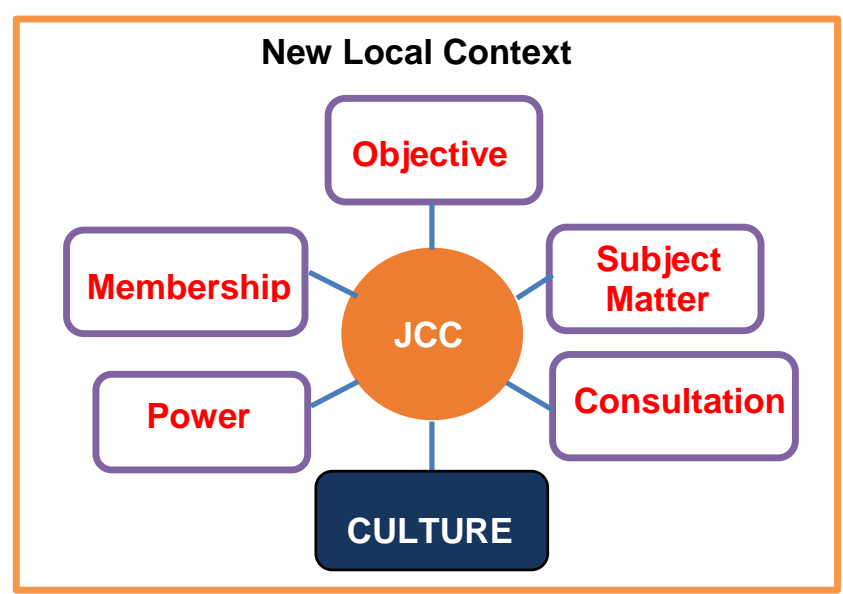

Fiqure 3 Suqqested modifications to JCC Model

If the university management is serious to do changes to the existing roles and functions of the Academic JCC it can help to increase the level of academic happiness working (Blayney, 2015) in a university environment. It is crucial to understand the happy, satisfied and motivated academic is the key for organization success because it builds up trust, honesty and confidence toward management commitment in organization; thus the national aspiration will be fulfilled respectively. In his recent message, the Vice Chancellor pointed on the aspiration of the Ministry of Education through public universities in the next five years to come. Among others is to achieve the global standing university ranking, top ten university ranking in the world, to be the center of excellence in Asian region, able to recruit the ablest and renowned scholars, to increase the number of international postgraduate students and to produce highly skilled, talented and motivated workforce.

To ensure the aspirations are being achieved, the JCC model must be modified for public universities to be effective. Most importantly, it is very crucial for the Academic JCC to be included as part of the organizational culture of the public universities. Subsequently, the question raised here is how to (i) institutionalized the new model; (ii) implement the process of internalization and socialization within the system the Academic JCC were established; and (iii) readiness of the management-Academic JCC-academician to accept the Academic JCC as a meaningful platform for management and academician as a whole unit united as one for positive outcomes (Marchington, 1992).

The study has developed into two implications. First, the study provides new idea, in terms of knowledge building through the re-conceptualizing the concept of JCC in the public higher education sector. Subsequently, the knowledge contribution on the theory can be used as reference to others in similar field of study. Second, the study provides valuable information to the policy makers and practitioners in this field to strategize on positive innovation work collaboration with the JCC.

\section{DIRECTION FOR FUTURE RESEARCH}

For further research, it is suggested to conduct studies in other public universities and to identify the specific culture needed for the Academic JCC to be effective indirect participation mechanism for both management and as the academic representation in order to be relevant in a public university environment.

\section{ACKNOWLEDGEMENT}

This research was financially supported by Universiti Malaysia Sabah.

\section{REFERENCE LIST}

Ab Rahman, B. (2012). "The Effectiveness of Joint Consultative Committee (JCC): A Case Study on Academic Staff Association in Universiti Malaysia Sabah". Unpublished Master of Philosophy theses 2012. Universiti Malaysia Sabah.

Ab Rahman, B., Parsuraman B. \& Rathakrishnan B. (2010). "Employee Participation in Organization: Rhetoric 
or Reality". Conference Proceeding in Regional Conference on Partnership between Community and Industry. 27-28 July 2010, University Malaysia Sabah.

Ab Rahman, B., Parasuraman, B., \& Rathakrishan, B. (2010). "Employee Participation in Public Sector in Malaysia: A General Overview". Conference Proceedings in the $7^{\text {th }}$ International Industrial Relations Association Congress, Bali, Indonesia 20-23 September 2010.

Maimunah, A. (2007). Malaysian Industrial Relations \& Employment Law. Kuala Lumpur: McGraw Hill.

Maimunah, A. (2009). Essentials of Employment \& Industrial Relations. Kuala Lumpur: McGraw Hill.

Arrigo, G., Casale, G., \& International Labour Office. (2010). A Comparative Overview of Terms and Notions on Employee Participation. Geneva: ILO.

Awang, S. (2010). "Public Sector Trade Unionism in Malaysia: A Practical Explanation". Conference Proceeding In $7^{\text {th }}$ International Industrial Relations Association Congress, Bali, Indonesia 20-23 September 2010.

Holden, L., \& Beardwell, I. (2001). Human resource management: A contemporary approach. Harlow: Financial Times Prentice Hall.

Blayney, M. (2015). "Profiting From Happiness”. Intheblack Magazine, CPA Australia, March 2015.

Blyton, P., \& Turnbull, P. (1998). The Dynamics of Employee Relations. Palgrave McMillan

Cabrera, E. F., \& Cabrera, A. L. (2003). "An Exploration O the Factors That Influence Employee Participation in Europe". Journal of World Business. 38, 1, 43-54. In view http://airenecon.ysyd.edu.au/parasuraman.pdf

CUEPACS, S.O. (2010, May 25). Direct and indirect participation in the public sector in Malaysia. (B. Ab Rahman, interviewer)

Cox, A., Marchington, M \& Suter, J. (2009). "Employee Involvement and Participation: Developing the Concept of Institutional Embeddeness Using WER2004". University of Strathclyde Glasgow

Farnham, D., (2000). Employee Relations in Context. London: Institute of Personnel and Development.

Goodijk, R. (2010). "Social Partnership in Europe: Some Reflection". Regional Conference on Partnership between Industry \& Community, Kota Kinabalu, Sabah.

Gollan, P. J. (2003). "All Talk But No Voice: Employee Voice at the Eurotunnel Call Centre". Economic and Industrial Democracy, 24, 4, 509-541.

Gollan, P. and Lewin, D. (2013). "Employee Representation in Non-Union Firms: An Overview". Journal of Industrial Relations. Vol. 52, No. S. 1. Wiley Periodical Inc.

Ramsay, H., Harley, B., Hyman, J. D., \& Thompson, P. (2005). Participation and Democracy at Work: Essays in Honour of Harvie Ramsay. Houndmills, Basingstoke, Hampshire: Palgrave Macmillan.

Hofstede, G. H., Hofstede, G. J., \& Minkov, M. (2010). Cultures and Organizations: Software of the Mind: Intercultural Cooperation and its Importance for Survival. New York: McGraw-Hill.

Hyman, J. D., \& Mason, B. (1995). Managing Employee Involvement and Participation. London: Sage Publications.

Idrus, D. (2001). "An Examination of the Contending Factors Shaping the Role of State in Malaysian Industrial Relations". Department of Management, Stirling. Unpublished PhD Thesis, Stirling.

Idrus, D. (2010). "Government Transformation Programme: Impact on HR and IR in Malaysia". Paper presented on $4^{\text {th }}$ November 2010 at Seminar Hubungan Industri dan Sumber Manusia, Universiti Malaysia Sabah

Kougiannou, K. (2013). "Effective Joint Consultative Committee: An Exploration on the Role of Trust and Justice". Durham thesis. Durham University. Available at Durham E-Theses Online http://etheses.dur.ac.uk/6911/

Kelly, D. (1999). Researching Industrial Relations. Leichardt, NSW: Federation Press.

Marchington, M. (1992). Managing the team: A guide to successful employee involvement. Oxford, OX, UK: Blackwell Business.

Marchington, M. (1994). "The Dynamics of Joint Consultation”. In Personnel Management: A Comprehensive 
Guide to Theory and Practice in Britain. K. Sisson. 2 ed. Oxford: Blackwell.

Markey, R., \& Monat, J. (1997). Innovation and employee participation through works councils: International case studies. Aldershot, Hants, England: Avebury.

Markey, R. (2001). "Global Patterns of Participation", in R. Markey, P. Gollan, A. Hodgkinson, A. Chouraqui and U. Veersma (eds.). Models of Employee Participation in a Changing Global Environment: Diversity and Interaction. Aldershot: Avebury. pp. 3-22.

Markey, R., \& Townsend, K. (2013). "Contemporary Trends in Employee Involvement and Participation". Journal of Industrial Relations. 55, 4, 475-487. Published online 23 July 2013 DOI: $10,1177 / 002213489389$

Mitchell, J.C. (1983). "Case and Situation Analysis". Sociology Review. 31(2), 187-211.

Okpu, T., \& Accra, J. S. (2014). "Joint Consultation and Workers Commitment in Nigerian Banking Industry". International Journal of Business and Management, 9, 3.

Parasuraman, B., \& Jones, M. L. (2006). Joint Consultative Committee in the Malaysian Postal Industry. University of Wollongon, Australia.

Parasuraman, B (2007). "An Examination of Employee Participation in the Private Sector: Malaysian Case Studies". Unpublished Doctor of Philosophy, University of Wollongong, Australia.

Parasuraman, B., Kelly, D., \& Rathakrishnan, B. (2009). "Employee Participation in the Private Sector in Malaysia: The Applicability of Favourable Conjunctures Model". Asean Marketing Journal. Vol.1-No. 2.

Ramsay, H. (1983). "Evolution or Cycle? Worker Participation in the 1970s and 1980s". In C. Crouch \& F. Heller.., International Yearbook of Industrial Democracy. United Kingdom: Wiley.

Raduan, C. R. (2002). Japanese-Style Management Abroad: The Case of Malaysian Subsidiaries. Petaling Jaya, Selangor, Malaysia: Prentice Hall.

Service Circular No 2, 1979 and No 7, 1989

Salamon, M. (1998). Industrial Relations: Theory and Practice. London: Prentice Hall.

Strauss, G. (1998). "Participation Works-If Conditions Are Appropriate". In E. P. Frank Heller. An Overview of Organization Participation: Myth and Reality (pp. 190-219). New York: Oxford University Press.

Strauss, G. (2006). "Worker Participation-Some Under-Considered Issues”. Worker participation-some underconsidered issues. Vol 4. 778-801.

Message from the Vice Chancellor. (2015, April 2). Retrieved from Universiti Malaysia Sabah:http://www.ums.edu.my/v5/en/about/message-from-the-vice-chancellor

Mohamed, D.M. (1991). The way forward Vision 2020. Retrieved from Wawasan 2020: http://www.wawasan2020.com/vision/

Wilpert, B. (1998). "Participation: View from Psychology". In E.P. Frank Heller. An Overview of Organizational Participation: Myth and Reality (pp. 40-64). New York: Oxford University Press.

Yin, R. K. (2003). Case Study Research: Design and Methods. Thousand Oaks, California: Sage Publications.

Zahari, I, (2013). Cross-Cultural Management: A Malaysian Perspectives. Cengage learning Asia Pte Ltd.

Zin, M.R. (1998). Participative decision making in the public sector. Universiti Kebangsaan Malaysia. 